\title{
Cambios fisiológicos, bioquímicos y ultraestructurales inducidos por el campo magnético en Synechocystis aquatilis
}

\section{(Physiological, biochemical and ultrastructural changes induced by static magnetic field in Synechocystis aquatilis)}

\author{
*L. Gomez Luna ${ }^{1,2}$, N. Steffanie ${ }^{3}$, T. Artoi ${ }^{3}$, A. Benitez Amaro ${ }^{1}$, \\ A. Moya Gomez ${ }^{4}$, A. Cuypers ${ }^{3}$ and N. Benaeerts ${ }^{3}$
}

${ }^{1}$ National Centre of Applied Electromagnetism, Universidad de Oriente, Cuba; ${ }^{2}$ Faculty of Agriculture and Environmental Science,Universidad Técnica Luis Vargas Torres, Ecuador, *lilimagl@gmail. com; ${ }^{3}$ Centre for Environmental Sciences, Research Group Zoology: Biodiversity \& Toxicology, Hasselt

University, Belgium; ${ }^{4}$ Biomedical Engeneering Department, Oriente University, Cuba.

\section{RESUMEN}

Los estudios ultraestructurales en Synechocystis se centran principalmente en el ficobilisoma (PBS); sin embargo existen pocos informes sobre el efecto del campo magnético a este nivel. El objetivo de la investigación fue examinar los principales efectos fisiológicos, cambios bioquímicos y ultraestructurales inducidos por el campo magnético estático (SMF) en un rango moderado de inducción ( $\beta$ : 35-45 $\mathrm{mT}$ ), con el fin de obtener evidencias para explicar la estrategia de respuesta a nivel celular y molecular de S. aquatilis (cepa local), explorando el potencial de SMF en el crecimiento y / o control de la toxicidad de esta cianobacteria ante mínimas variaciones del campo. Los cultivos control alcanzaron la máxima densidad celular el día 15, pero aquellos expuestos a 37,7 mT obtuvieron máximos el día 7, mientras que los expuestos a 44,3 $\mathrm{mT}$ el día 13, con diferentes valores de $\mathrm{k}_{\text {máx }}$ : 8 826,67 \pm 538,40; $4175,00 \pm 459,62$ y $3943,75 \pm 937,71$, respectivamente $(\alpha=0,05)$. De acuerdo con las evidencias ultraestructurales se observan modificaciones en la disposición de los tilacoides inducida por SMF, variando la distribución y las distancias entre los tilacoides y las membranas tilacoidales. Estos cambios deben tener implicación a nivel funcional, probablemente como respuesta celular para mantener la eficiencia fotosintética. Los resultados sugieren que el SMF (37,7 y 44,3 mT) induce cambios significativos en el crecimiento y la ultraestructura de esta cianobacteria planctónica, y cambios discretos moleculares que implican a la composición pigmentaria y el potencial tóxico.

Palabras clave: Cianobacterias, pigmento, potencial tóxico, el campo magnético. 


\begin{abstract}
Ultrastructural studies of Synechocystis mainly focus on phycobilisoma (PBS). There are few reports about the magnetic field effect at this level. The objective of this study was to examine the main physiological, biochemical and ultrastructural changes induced by static magnetic field (SMF) in a moderate strength magnetic field range ( $\beta$ : 35-45 $\mathrm{mT}$ ). The purpose of this examination was obtaining evidence to explain the response strategy at the cellular and molecular level of Synechocystis aquatilis (local strain), even with minimal induction changes, exploring the SMF potential over the growth and/ or toxicity control. Control cultures reach the maximum cell density at day 15, but with $37.7 \mathrm{mT}$ at day

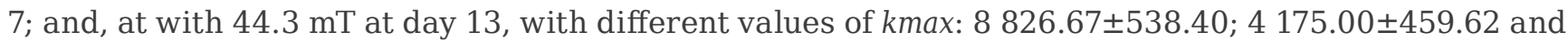
$3943.75 \pm 937.71$, respectively $(a=0.05)$. According to the ultrastructural evidence, there were modifications on thylakoid arrangement induced by SMF varying the distribution and distances between thylakoids and thylacoidal membranes. These changes should have implication at the functional level; probably as a resultant cellular response to maintain the photosynthetic efficiency. Results suggest that the SMF (37.7 and $44.3 \mathrm{mT}$ ) induces significant changes in growth and ultrastructure of this planktonic cyanobacterium, and discrete molecular changes which involve the pigment composition and toxic potential.
\end{abstract}

Keywords: Cyanobacteria, pigment, toxic potential, magnetic field.

\title{
40 Cumbres
}




\section{INTRODUCTION}

Exposure to magnetic fields has increased significantly over the years due to man-made activities and devices; for this reason the study of magnetic field effects (MFE) in biological systems, including humans, has gained interest, especially in the last two decades, mainly because of the understanding of the mechanism of action. Static or constant and pulsing magnetic fields and direct and alternating electric currents might be applied to regulate (stimulate or inhibit) cell proliferation or to monitor cell growth and other metabolic activities, increasing the use and benefits in microbial biotechnology (Elahee \& Poinapen, 2006; Gómez, Menéndez, Álvarez, \& Flores, 2009; Mihoub, El May, Aloui, Chatti, \& Landoulsi, 2012; Velizarov, 1999; Wang, Zeng, \& Gui, 2006).

Even when all life on earth has being influenced by electric and magnetic fields, it is still not fully understood the mechanism responsible for the magneto-sensitivity, and little is known about the influence of magnetic fields on microorganism ultrastructure.

Synechocystisis is an unicellular, photoautotrophic, facultative glucose-heterotrophic cyanobacteria that can survives and grows under a wide range of environmental conditions. Synechocystis has biotechnological interest, mainly to lipid extraction (Kaiwan-Arporn, Hai, Thu, \& Annachhatre, 2012) and for large-scale purification of C-phycocyanin (Ramos, 2011; Ugwu, 2005). Nevertheless, because of a blooming capacity and toxicity of some species, it can become a problem in large scale cultures.

The majority of the studies about the magnetic field effect on living organisms, discuss one of the following theoretical mechanisms: the magnetite mechanism, not valid in Synechocystis, because of the lack of magnetosomes, and the radical pair mechanism (Y. Liu, 2008).The objective of the current research was to examine the main physiological, biochemical and ultrastructural changes induced by SMF in a moderate strength magnetic field range ( $\beta$ : 35-45 $\mathrm{mT}$ ) in order to obtain evidences to explain the response strategy at cellular and molecular level of this cyanobac- teria, exploring the SMF potential in the growth and/or toxicity control of $S$. aquatilis. These results were verified on growth kinetics, pigment content (chlorophyll $a$ and C-phycocyanine), toxic potential measured as percentage of phosphatase inhibition and ultrastructural changes by transmission electronic microscope (TEM).

\section{MATERIALS AND METHODS}

Culture of Synechocystis cells: wild strain of the cyanobacteria Synechocystis aquatilis Sauvageau 1892: cxv (Synechococcales; Merismopediaceae) was isolated from a water reservoir (Chalóns, Santiago de Cuba) developing dense cultures in controlled experimental condition. The deposit code of the strain in the culture collection is CNEA-F140011-N-4014, culture collection subscribed to FELAC.

S. aquatilis was choose due to its structural simplicity and singularities, availabilty in aquatic (local) tropical ecosystems, ultrastructural studies previous reports, biotechnolgical interest, growth rate and toxic potential. It is important to remark that toxic cyanobacteria, their proliferation and toxin production strains is till nowadays a complex topic; cyanotoxins are one of the most toxic substances in the water mass, due to their distribution and toxic effect (Pérez, Soraci, \& Tapia, 2008).

Asynchronic dense cultures of monospecific $S$. aquatilis were developed indoors during 15 days, in controlled laboratory conditions, using a 500 $\mathrm{mL}$ flask as photobioreactor with an initial concentration $(\mathrm{Ci})=500 \times 10^{4}$ cell. $\left.\mathrm{mL}^{-1}\right)$. Cells grew photoautotrophically in B12 (Shirai et al., 1989) liquid medium $\left(\mathrm{NaNO}_{3}\right.$ as main nitrogen source)

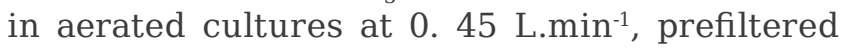
air, using a glass microfiber syringe filter Midisart 2000 Sartorius 0. $20 \mu \mathrm{m}$ and $\mathrm{pH}=7.5$. Aeration allows an homogenous growth of the cells (Raven, 1988). The culture was supplied with 0 , $3 \% \mathrm{CO}_{2}$, favoring photoautotrophic metabolism and the culture buffering.

Culture temperature was around 20.00 $\pm 1.0^{\circ} \mathrm{C}$ and the irradiance, $58.59 \mathrm{\mu Em}^{-2} \mathrm{~s}^{-1}$; these 
parameters fall on the range recommended by some authors (Boulay, Abasova, Six, Vass, \& Kirilovsky, 2008; Ikeuchi \& Tabata, 2001; Laczko-Dobos et al., 2008; Mattoo, Giardi, Raskind, \& Edelman, 1999; Nascimento \& Azevedo, 1999; Olive, Ajlani, Astier, Recouvreur, \& Vernotte, 1997; Pawlik-Skowrofiska, 1997). Continuous light was supplied by means of PHILIPS DAYLIGHT, $32 \mathrm{~W}$ (TLD 32 W/865-NG) lamps. The light intensity was measured and corrected daily with a digital Voltcraft MS 1300 lux meter. Biomass was collected by centrifugation and immediately cooled at $4^{\circ} \mathrm{C}$ until the analyses.

Magnetic field arrangement and doses: static magnetic field treatment was applied to the whole culture during $1 \mathrm{~h}$ at two different induction values: $37.7 \mathrm{mT}$ and $44.3 \mathrm{mT}$ during the early exponential phase (day $7^{\text {th }}$ ). The $\beta$ values were selected considering different criteria (Hirano, Ohta, \& Abe, 1998; Y. Z. Liu, Wang, Ru, \& Zhao, 2008; Singh, Tiwari, Abraham, Rai, \& Rai, 1994; ZhiYong, Si-Yuan, Lin, \& Miao-Yan, 2007). The reproducibility of all data in this study was confirmed by five repetitions.

Magnetos arrangement: two neodymium magnets arrangements were used to supply non-homogeneous magnetic fields. There were build and characterized in the National Centre of Applied Electromagnetism, Cuba. The $\beta$ statistic in the work region (cylinder $8.4 \mathrm{~cm}$ diameter and 9. 7 $\mathrm{cm}$ length, collinear with magnet axis and centered on it) to arrangement $A$, have an average of 37. $7 \mathrm{mT}$; maximum value of $87.9 \mathrm{mT}$ and minimum $13 \mathrm{mT}$ (SD: 10. $4 \mathrm{mT}$ ). To the arrangement $\mathrm{B}$, the average is $44.3 \mathrm{mT}$; maximum value of 103 . $4 \mathrm{mT}$ and minimum 15. $3 \mathrm{mT}$ (SD: $12.2 \mathrm{mT}$ ). In order to avoid any interference, cultures were developed in areas with values below $0.25 \mu \mathrm{T}$. The low frequency electromagnetic interference (LFEI) (300 Hz) was measured with a Tester TES 1390 (0. 01 y $1999.9 \mu \mathrm{T}$ ) in the culture chamber. The work range was 0.011 to $2.27 \mu \mathrm{T}$, lower than the limit established to public environment exposure, according to World Health Organization, specifically the International Commission for No Ionizing Radiation Protection (ICNIRP): $83 \mu \mathrm{T}$ (OMS, 2008).
Cells counting and growth parameters: Growth parameters were analyzed daily; other analyses were made at the end of the experiment (day 15). Algal densities were determined by daily counting triplicate samples in a Neuberger improved haematocytometer. Results were expressed in cell. $\mathrm{mL}^{-1}$. Previous to the experiments with $\mathrm{SMF}$, the $S$. aquatilis control culures $(\mathrm{Ci}=500.00$ $\pm 56.55 \times 10^{4}$ cell. $\left.\mathrm{mL}^{-1}\right)$ kinetic were studied.

The media, exponential $\left(\mu_{\text {med }}\right)$ and maximum growth rate $\left(\mu_{\text {máx }}\right)$ were calculated from the number of cells values daily base. It represents the inverse of the duplication time (DT) which means the time that $\mathrm{N}$ cell needs to be transformed in $2 \mathrm{~N}$ cells during the exponential phase. It was calculated using the following equation and expressed as divisions per day:

$$
\mu\left(\operatorname{div} \cdot \operatorname{day}^{-1}\right)=\left(\log 2\left(\mathrm{~N}_{\mathrm{t}}\right)-\log 2\left(\mathrm{~N}_{0}\right)\right) /\left(\mathrm{t}_{\mathrm{t}}-\mathrm{t}_{0}\right)
$$

Where: $\mathrm{N}_{\mathrm{T}}$ and $\mathrm{N}_{0}$ are cellular densities (cell.mL $\left.{ }^{1}\right)$ at time $t$ and 0 respectively.

Phosphatase inhibition test: in order to evaluate the effect of SMF over the toxic potential of S. aquatilis cells, the phosphatase inhibition test was developed. The percentage of inhibition was calculated considering the maximum enzymatic activity. It was determined spectrophotometrically at $405 \mathrm{~nm}$, during $3 \mathrm{~min}$. A blank with bidistillated water was used. A positive control (buffer phosphate) was also prepared. The enzymatic activity was calculated with the following equation (Bessey, Lowry, \& Brock, 1946; Kuwana \& Rosalki, 1991):

$$
\operatorname{Activity}\left(\mathrm{U} \mathrm{L}^{-1}\right)=\Delta \mathrm{OD} \mathrm{min}^{-1} \times 2750
$$

\section{Enzymatic activity factor: 2750}

Pigment analysis and chlorophyll a: C-phycocyanine ratio: To evaluate the effect of SMF over the cellular pigment composition in $S$. aquatilis, the ratio of the main pigments were analyzed (chlorophyll a: C-phycocyanine). It was evaluated considering their usefulness as indicator of culture status and to evaluate the environmental acclimation cell response strategy (Gómez, 1997). Cell pigments were extracted with $5 \mathrm{~mL}$ of methanol $99.8 \%$ ac- 
cording to modified ISO 10260 procedure (ISO, 1992) including $5 \mathrm{~min}$ of dark-iced disruption in an Ultrasonic chamber Scientz-IID, 20-25 Hz and $80 \%$ of pulse ratio. Cells were resuspended by vortex-shaken for $10 \mathrm{~s}$ and centrifuged at $2540 \mathrm{~g}$ for $10 \mathrm{~min}$. The chlorophylls $a$ were spectrophotometrically determined by recording the absorbance at $665 \mathrm{~nm}$, using the molar extinction coefficient $74.46 \mathrm{~mL} \mathrm{mg}^{-1} \mathrm{~cm}^{-1}$ (Rivas, Fontes, Moreno, Rodríguez, \& Vargas, 1992) with the equation:

Chlorophyll $a\left(\mu \mathrm{g} \mathrm{mL} \mathrm{m}^{-1}\right)=13.43 \times(\mathrm{A} \mathrm{665}) *(\mathrm{VEx}-$ tract / VCulture)

Pheopigments were determined by sample acidification with methanol extract $(0.1 \mathrm{~mL} \mathrm{HCl}, 3 \mathrm{M})$, during $5 \mathrm{~min}$. Corrections were made with the absorbance at $750 \mathrm{~nm}$. Pheopigments were spectrophotometrically determined by recording the absorbance at $665 \mathrm{~nm}$. Results were expressed in ng cell-1.

The C-phycocyanine (C-PC) was extracted according to Boussiba y Richmond with $5 \mathrm{~mL}$ of buffer phosphate $100 \mathrm{mM}\left(10.64 \mathrm{gL}^{-1} \mathrm{de} \mathrm{K}_{2} \mathrm{HPO}_{4} \mathrm{y}\right.$ $5.29 \mathrm{gL}^{-1}$ de $\mathrm{KH}_{2} \mathrm{PO}_{4}$ a pH 7) freezing at $4^{\circ} \mathrm{C}$, overnight, in dark conditions (Boussiba \& Richmond, 1979); then the cells were re-suspended by vortex-shaken for $10 \mathrm{~s}$ and centrifuged at $2540 \mathrm{~g}$ for $10 \mathrm{~min}$. The spectrophotometric determination was made by recording the absorbance at 615 , 652 y $730 \mathrm{~nm}$. To calculate the concentration, the following equation was used (Sigelman \& Kycia, 1978). Results were expressed as ng cell..$^{-1}$.

$\mathrm{C}-\mathrm{PC} \quad\left(\mu \mathrm{g} \quad \mathrm{mL}^{-1}\right)=\left(\mathrm{A}_{615}-\mathrm{A}_{730}-0.47\left(\mathrm{~A}_{652}-\mathrm{A}_{730}\right)\right) / 5$. $\left.34 *\left(\mathrm{~V}_{\text {Buffer }} * 1000\right) / \mathrm{V}_{\text {Culture }}\right)$

Statistical Analysis: growth parameters, toxic potential and pigment content were analyzed, considering $5 \%$ of significance in the mean differences, by one-way ANOVA followed by Tukey-Kramer's HSD post-test, using ORIGIN 6.0 and/or SPSS PASW 18 software. A Pearson correlation was made to analyze the relation between growth and toxic potential.

Transmission electron microscopy and images analyses: cells were spun in $1 \mathrm{~mL}$ centrifuge vials at $13000 \mathrm{x} \mathrm{g}$ for $5 \mathrm{~min}$ to form a pellet and rinsed 2 times with PBS. Approximately $20 \mu \mathrm{L}$ aliquots of the cell pellet (PBS preparations) were fixed with $2 \%$ glutaraldehyde in $0.1 \mathrm{M}$ dimethyl arsenic acid sodium salt trihydrate buffer $\mathrm{pH}$ 7. 2 overnight at $4^{\circ} \mathrm{C}$. After glutaraldehyde fixation samples were rinsed 3 times 30 min $4^{\circ} \mathrm{C}$ with the same buffer and post fixated during $2-3 \mathrm{~h} 4^{\circ} \mathrm{C}$. This step was followed by a rinsing sequence ( 3 times x $5 \mathrm{~min}$ ) at room temperature with distilled water. After that, dehydration was developed with successive steps at room temperature: acetone $50 \%$ (20 $\mathrm{min})$; acetone $70 \%$ (30 $\mathrm{min})$; acetone $90 \%$ (30 min); acetone $100 \%$ (30 min) and acetone absolute (30 min). The samples were then rinsed in three changes of anhydrous acetone at $-85{ }^{\circ} \mathrm{C}$ before being placed in a $1 \% \mathrm{OsO}_{4}$ solution in acetone and slowly warmed to room temperature over a six-hour period (A. M. L. van de Meene, Hohmann-Marriott, Vermaas, \& Roberson, 2006; A. M.L. van de Meene et al., 2012).

The cells were then rinsed in acetone and slowly infiltrated with and polymerized in Spurr's resin (Spurr, 1969). The impregnation was made in acetone: Spurr (1:1) overnight in rotator at room temperature and then embedding in rubber molds, polymerizing in the oven at $70^{\circ} \mathrm{C}$, around $17 \mathrm{~h}$.

Embedded cells were cut into serial $70 \mathrm{~nm}$ thick sections with an Ultracut $\mathrm{R}$ Microtome (Leica, Vienna, Austria) and collected on Formvar-coated copper slot grids. Sections were post-stained with $2 \%$ uranyl acetate in $50 \%$ ethanol for $5 \mathrm{~min}$.

The grids were carbon-coated. At least 100 random cell images were taken from different samples, but only 25 images were recorded for images analyses. Electron microscopy was performed on a PHILIPS CM 12-STEM electron microscope operated at $120 \mathrm{kV}$ at University of Hasselt, Belgium. Images were recorded under low dose conditions (a total dose $\sim 25$ e-/ 2 ) with a 4000 SP 4 K slow-scan camera (Gatan, Pleasanton, CA) at-390 $\mathrm{nm}$ defocus and at a magnification of 80.000. The pixel size (after binning the images) was 3. $75 \AA$ at the specimen level and GRACE software was used for semi-automated 
specimen selection and data acquisition. The image analysis was performed with the Image Tool v 3.0 Processing software on a PC cluster; 10 measurements were made by each picture. Oneway ANOVA was used to compare mean differences at $5 \%$ level of significance.

\section{RESULTS AND DISCUSSION}

Physiological changes (growth and survival): in control cultures, S. aquatilis cell reach the exponential growth early in day 3 until day 15, but at day 12 a slope change was visible (Fig. 1), beginning a decrease in the growth rate.

As result of the exposure to SMF, significant differences of cell density values $(\alpha=0.05)$ were observed in those cultures in relation to controls. There was an inmediate cell density drop $24 \mathrm{~h}$ after the SMF application for both inductions. In cultures exposed at $37.7 \mathrm{mT}$ cells population were decreased at $11 \%$ (3 $612.5 \pm 548.01 \times 10^{4}$ cell.mL $\left.{ }^{1}\right)$ in relation to controls ( $4048.67 \pm 466.89 \times 10^{4}$ cell. $\left.\mathrm{mL}^{-1}\right)$. In those exposed to $44.3 \mathrm{mT}$ there was a decrease of $25 \%$ (3 $040.63 \pm 181.51 \times 10^{4}$ cell. $\left.\mathrm{mL}^{-1}\right)(\alpha=0.05)$. At the end of the experiment (day 15) control cell density value was $8826.67 \pm 538$. $40 \times 10^{4}$ cell. $\mathrm{mL}^{-1}$. The minimum value was obtained at $37.7 \mathrm{mT}\left(1650.00 \pm 212,13 \times 10^{4}\right.$ cell. $\left.\mathrm{mL}^{-1}\right)$ (Fig. 1, Table 1). The exponential and maximum growth rate $\left(\mu_{\exp }\right.$ and $\left.\mu_{\max }\right)$ are showed in table 1 as well as the maximum cell density to each treatment $\left(k_{\max }\right)$, and the cell density at the end of the exponential phase 15 ( $k 15)$.

Values of exponencial and maximum growth rate in control cultures and those exposed to SMF had significant differences, being higher $(\alpha=0.05)$ in the SMF exposed cultures. Control cultures reach the maximum cell density at day 15 , but at $37.7 \mathrm{mT}$ in the day 7 and at $44.3 \mathrm{mT}$ in the day 13, with different values of kmax: 8 826.67 $\pm 538.40,4$ $175.00 \pm 459.62$ and $3943.75 \pm 937.71$, respectively $(\alpha=0.05)$.

- Biochemical changes: toxic potential and pigments content

- Toxic potential: There is no correlation between both parameters ( $\mathrm{r}=0.82$, Pearson; $\alpha=0.05)$ and no significant differences in the inhibition percentage $(\alpha=0.05)$ were obtained. It was higher than $50 \%$ for all the treatments, but slightly higher than $55 \%$ to $44.3 \mathrm{mT}$

- Pigment content and ratio: Pigment variation was not statistically significant $(\alpha=0.05)$; but minimum concentration was obtained at 37. $7 \mathrm{mT}\left(22.59 \pm 0.21 \mathrm{ng}\right.$ cell $\left.^{-1}\right)$, and maximal C-phycocyanine concentration was reached at $44.3 \mathrm{mT}(6.81 \pm 2.11 \mathrm{ng}$ cell ${ }^{-1}$ ) (Fig. 2).

- The ratio chlorophyll $a: C$-phycocyanin (Chl:Phy) was about 5.5 in control cultures $(\alpha=0.05)$ but it dropped when cultures were exposed to SMF ( $\leq$ Chl:Phy $\leq 5)$.

Ultrastructure: some ultrastructural changes were verifyed in S. aquatilis cells exposed to SMF (Fig. 3).

The main differences were found in cell size, wall thickness and aparience, thylacoids arrangement and store granules presence. Cell size in control cultures and in cultures exposed to SMF is presented in table 2 .

There were significant differences in both cell length and cell width, between all the treatments, being smallest the control cells, and largest those from cultures exposed to $44.3 \mathrm{mT}$. These are evidences of ultrastructural changes in Synechocystis aquatilis cells produced by SMF and would be related with subcellular arrangement and cell viability and/or efficiency. There are visible differences on the outer layer of the cell wall; it is smooth and slimmer in controls, but thicker in those cells exposed to SMF.

Specifically at $44.3 \mathrm{mT}$ the cell wall seems wavy and rough, resembling a quiescent state. About the thylakoids membranes (TM) S. aquatilis control cells have a concentrically TM distributed on the cell periphery, but with the SMF this arrangement was modified (Fig. 3). There were a disaggregation of the staked thylacoidal membrane in SMF exposed cells and the cyanophycine granules displace it, at $37.7 \mathrm{mT}$, modifying the initial appearance. The granules are conspicuous at $37.7 \mathrm{mT}$ (around $0.5 \mu \mathrm{m}$ ); presumably

\section{$44 \quad$ Cumbres}




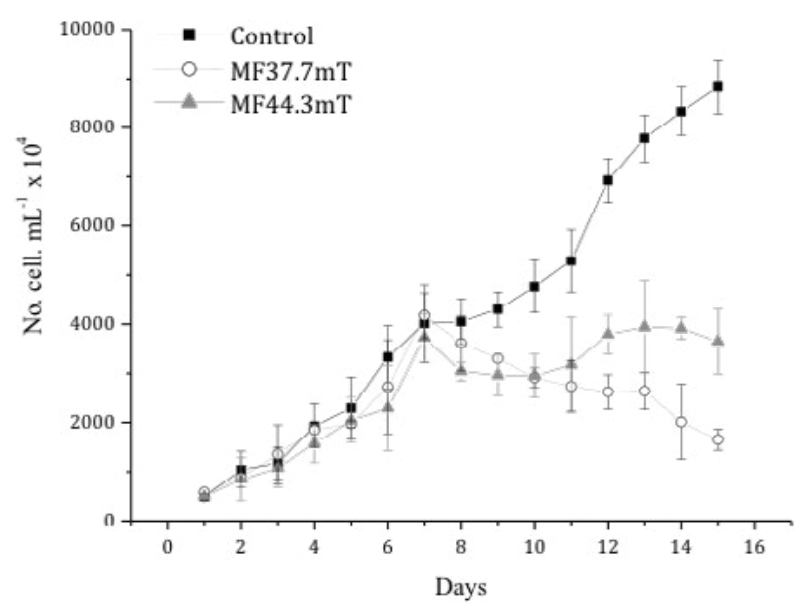

Fig.1. Growth kinetic of $S$. aquatilis control cultures and those expoused to SMF $(b=37.7 \mathrm{mT}$ and $44.3 \mathrm{mT})$ (Media $\pm \mathrm{SE} ; \mathrm{n}=5)$ at $58.59 \mu \mathrm{Em}^{-2} \mathrm{~s}^{-1}$.

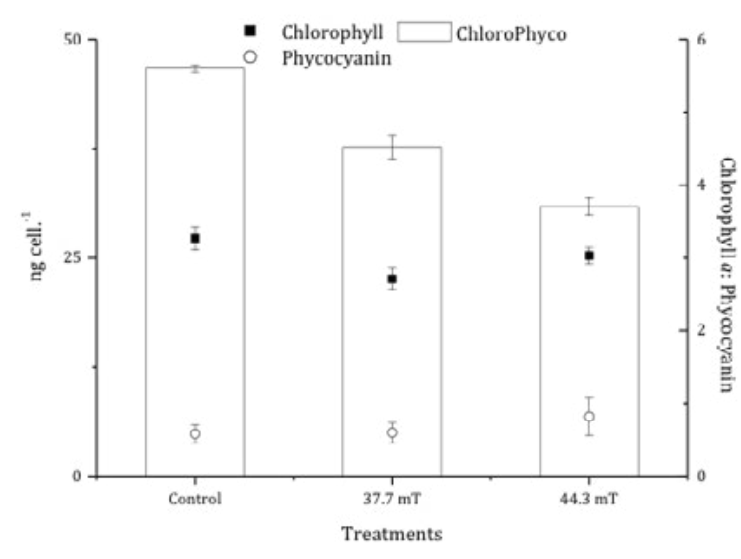

Fig. 2. Variation of the pigment concentration (chlorophyll $a$ and C-phycocyanine) in S. aquatilis culture (day 15) at $58.59 \mathrm{\mu Em}^{-2} \mathrm{~s}^{-1}$, control culture and culture exposed to SMF: 37.7 y $44.3 \mathrm{mT}$ and chlorophyll $a$ : $C$-phycocyanin (Chl:Phy) ratio (Media $\pm \mathrm{SE}$; $\mathrm{n}=5$ ).

Table 1. Exponencial and maximum growth rate, and cellular density in S. aquatilis cultures (control and SMF exposed cultures)

\begin{tabular}{|c|c|c|c|c|}
\hline & $\begin{array}{c}\mu \exp \\
{\left.\text { (div. } \text { day }^{-1}\right)}\end{array}$ & $\underset{{\left.\text { (div. } \text { day }^{-1}\right)}_{\operatorname{umax}}}{\max }$ & $\underset{(\mathrm{d})}{\left.k \operatorname{xi10^{4}} \text { cell. } \mathrm{mL}^{-1}\right)}$ & $\begin{array}{c}k 15 \\
\left(x 10^{4} \text { cell. } \mathrm{mL}^{-1}\right)\end{array}$ \\
\hline Control & $0.2430 \pm 0.01^{\mathrm{a}}$ & $0.2694 \pm 0.02^{\mathrm{a}}$ & $8826.67 \pm 538.40^{(15) a}$ & $8826.67 \pm 538.40^{a}$ \\
\hline $37.7 \mathrm{mT}$ & $0.4508 \pm 0.02^{\mathrm{b}}$ & $0.5399 \pm 0.01^{b}$ & $4175.00 \pm 459.62^{(7) b}$ & $1650.00 \pm 212.13^{b}$ \\
\hline $44.3 \mathrm{mT}$ & $0.4310 \pm 0.04^{b}$ & $0.4343 \pm 0.03^{c}$ & $3943.75 \pm 937.71^{(13) c}$ & $3648.00 \pm 655.41^{c}$ \\
\hline
\end{tabular}

$d^{*}$ : day when the culture reach the maximum cell density

Diferent letters in columns indicate significant differences $(\alpha=0.05)$.

Values represent mean \pm SE.
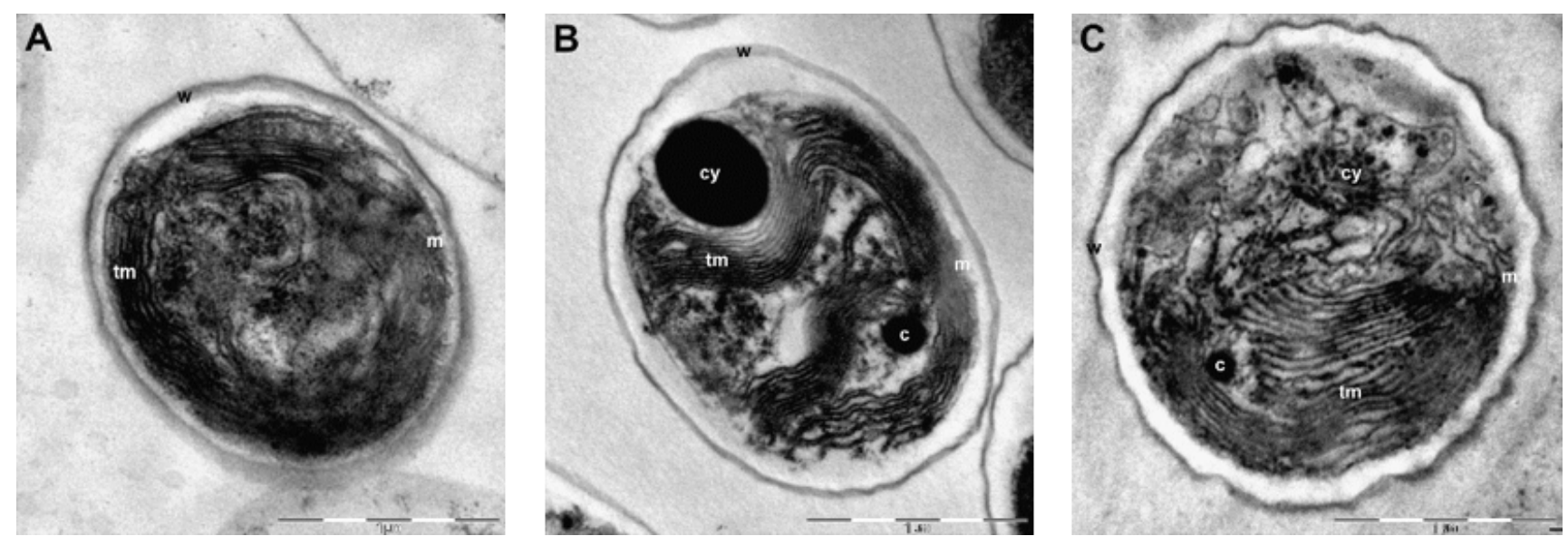

Fig. 3. TEM images of ultraestructural changes in Synechocystis aquatilis; control cultures (A) and cultures exposed to SMF: 37.7 (B) and $44.3 \mathrm{mT}$

(C). C: carboxysome; CY: cyanophycine granule; tm: thylakoid membrane, m: cellular membrane.

these are formed by the accumulation of store substances like cyanophycine, which can content amino acids like arginine and aspartic acid (Bold \& Wyne, 1985), and/ or pigments. Otherwise, car- boxysomes or polyhedral bodies (around $0.5 \mu \mathrm{m}$ ) were visible in cells exposed to SMF, both at 37. 7 and $44.3 \mathrm{mT}$.

Studies on the possible effects of SMF have 
Table 2. Cell size measurements: media values and ES (control and SMF exposed cultures)

\begin{tabular}{|c|c|c|c|c|}
\hline & $\underset{\text { (div. day }^{-1} \text { ) }}{\boldsymbol{\mu}_{\exp }}$ & $\underset{\left.\text { (div. day }^{-1}\right)}{\mu_{\max }}$ & $\begin{array}{c}k_{\max } \\
\left(\mathrm{d}^{*}\right)^{\left(\times 10^{4} \text { cell. } \mathrm{mL}^{-1}\right)}\end{array}$ & $\begin{array}{c}k_{15} \\
\left(\times 10^{4} \text { cell. } \mathrm{mL}^{-1}\right)\end{array}$ \\
\hline Control & $0.2430 \pm 0.01^{\mathrm{a}}$ & $0.2694 \pm 0.02^{\mathrm{a}}$ & $8826.67 \pm 538.40^{(15) a}$ & $8826.67 \pm 538.40^{a}$ \\
\hline $37.7 \mathrm{mT}$ & $0.4508 \pm 0.02^{b}$ & $0.5399 \pm 0.01^{b}$ & $4175.00 \pm 459.62^{(7) b}$ & $1650.00 \pm 212.13^{b}$ \\
\hline $44.3 \mathrm{mT}$ & $0.4310 \pm 0.04^{b}$ & $0.4343 \pm 0.03^{c}$ & $3943.75 \pm 937.71^{(13) c}$ & $3648.00 \pm 655.41^{\mathrm{c}}$ \\
\hline
\end{tabular}

Diferent letters in ES columns indicate significant differences $(\alpha=0.05)$.

been conducted in different systematic groups and with diverse experimental conditions (Elahee \& Poinapen, 2006). Even when detectable changes are often observed in exposed biological systems, the findings are usually statistically non significant comparing with controls, or there are contradictory effects described or erratic behaviors (Halpern, 1969; Pazur \& Scheer, 1992).

According to the experimental evidences the number of cells of $S$. aquatilis decline inmediatily after the SMF exposure (both inductions). Furthermore, an apparent shortening of the exponential phase was observed, but cultures keep growing till day 15. Results showed a strong inhibitory effect of SMF over $S$. aquatilis cell growth, higher at $37.7 \mathrm{mT}(\alpha=0.01)$ than at $44.3 \mathrm{mT}$. The kinetic study showed that there are at least two responses: an inmediate system perturbation response $\mathrm{R}(\mathrm{t} 1)$ which was veryfied with a cellular decline $24 \mathrm{~h}$ after the exposure $=\mathrm{R}(24 \mathrm{~h})$ and a late system recovery tendency response $\mathrm{R}(\mathrm{t} 2)$ which begun $96 \mathrm{~h}$ till the final culture decline $=\mathrm{R}(96 \mathrm{~h})$. It was verifyied with the growth rate data analysis.

It seems that SMF gradient affects immediately the $S$. aquatilis kinetic when cultures were exposed for $1 \mathrm{~h}$ to the magnet arrangement during the early exponential phase, inducing a strees response with two main components: $R(24 h)$ and $\mathrm{R}(96 \mathrm{~h})$. A culture aging and a drastically cell density decreasing was the final consequence of the SMF exposure. Probably, these two responses modulate the growth kinetic, depending of the induction, being $37.7 \mathrm{mT}$ those that induces the highest growth inhibitory effect.

After $24 \mathrm{~h}$ of SMF exposure, the cell population of cultures exposed to $37.7 \mathrm{mT}$ decreases 11 $\%$ in relation to the control culture; but after $96 \mathrm{~h}$ it decreases $14 \%$, in relation with those exposed to $44.3 \mathrm{mT} \mathrm{SMF} \mathrm{(2} 737.50 \pm 512.65 \times 10^{4}$ cell. $\mathrm{mL}^{-1}$ vs $3171.88 \pm 968.51 \times 10^{4}$ cell. $\mathrm{mL}^{-1}$ ) and $48 \%$ in relation to control cultures (5 $291.67 \pm 630.53 \mathrm{x}$ $10^{4}$ cell.mL $\left.\mathrm{m}^{-1}\right)(\alpha=0.05)$.

As a general view, the mortality rate was higher than the growth rate after the SMF exposure. Seemingly the exposition to a SMF at $37.7 \mathrm{mT}$ did not allow the microorganisms recovery and $\mathrm{R}(24 \mathrm{~h})$ was the main component.

The pigment content and ultrastructure analyses confirmed an early senescence resulting in premature decline of cultures exposed to SMF, usually attributable to a strees response. The TM dispersion observed in cell exposed to SMF could be related with the integrity loss because of a permanent damage induced by SMF, which depend on the doses.

At ultrastructure level there were in some segments of the plasma membrane evidences of the integrity loss, confirming this explanation. In overall, these results suggest that the SMF into the study range (37. 7 and $44.3 \mathrm{mT}$ ) induces significant changes in growth and ultrastructure of the planktonic cyanobacteria Synechocystis aquatilis, with molecular discrete changes which involve the pigment composition and toxic potential.

\section{ACKNOWLEDGMENTS}

The Laboratory of Ecotoxicology and Environmental Services team wants to thanks the support of the VLIR-IUCUO Project between the Universidad de Oriente and Universities of Belgium, "University of East Promotes a sustainable development in the Eastern Region of Cuba" especially to Hasselt University, a partner of Subproject 1 .

\section{Cumbres}




\section{REFERENCES}

Bessey, O. A., Lowry, O. H., \& Brock, M. J. (1946). A method for the rapid determination of alkaline phosphates with five cubic millimeters of serum. Journal of Biological Chemestry, 164, 321329.

Bold, H. C., \& Wyne, M. J. (Eds.). (1985). Introduction to the Algae: structure and reproduction (Vol. 2). New Jersey, USA: Ed. Prentice-Hall Inc.

Boulay, C., Abasova, L., Six, C., Vass, I., \& Kirilovsky, D. (2008). Occurrence and function of the orange carotenoid protein in photoprotective mechanisms in various cyanobacteria. Biochimica Et Biophysica Acta-Bioenergetics, 1777(10), 1344-1354. doi: DOI 10.1016/j.bbabio.2008.07.002

Boussiba, S., \& Richmond, A. (1979). Isolation and characterization of phycocyanins from the blue-green alga Spirulina platensis. Archives of Microbiology, 120, 155-159.

Elahee, K. B., \& Poinapen, D. (2006). Effects of static magnetic fields on growth of Paramecium caudatum. Bioelectromagnetics, 27, 26-34.

Gómez, L. (1997). Cultivo y aplicación de las microalgas Dunaliella salina y Chlorella vulgaris en Cuba. (Doctorado Tesis de Doctorado), Universidad de La Coruña, La Coruña. Retrieved from http://ruc.udc.es/dspace/handle/2183/5592 Servicio de Publicaciones. Universidad de La Coruña database.

Gómez, L., Menéndez, J., Álvarez, I., \& Flores, I. (2009). Efecto de diferentes protocolos de aplicación de un campo magnético (0.03T) sobre el crecimiento, viabilidad y composición pigmentaria de Haematococcus pluvialis Flotow en suficiencia y ausencia de nitrógeno. Biotecnología Vegetal, 9(2), 105-117.

Halpern, E. (1969). Biological effects of magnetic fields (Vol. 2). New York, USA: Plenum Press.

Hirano, M., Ohta, A., \& Abe, K. (1998). Magnetic field effects on photosynthesis and growth of the cyanobacterium Spirulina platensis. Journal of Fermentation \& Bioengineering, 86(3), 313-316. doi: 10.1016/S0922-338X(98)80136-0

Ikeuchi, M., \& Tabata, S. (2001). Synechocystis sp. PCC 6803 - a useful tool in the study of the genetics of cyanobacteria. Photosynthesis Research, 70(1), 73-83. doi: Doi 10.1023/A:1013887908680

Water quality - Measurement of biochemical parameters - Spectrometric determination of the chlorophyll-a concentration, ISO 10260 C.F.R. § 10260: 1992 (E) (1992).

Kaiwan-Arporn, P., Hai, P. D., Thu, N. T., \& Annachhatre, A. P. (2012). Cultivation of cyanobacteria for extraction of lipids. Biomass \& Bioenergy, 44, 142-149. doi: DOI 10.1016/j.biombioe.2012.04.017

Kuwana, T., \& Rosalki, S. B. (1991). Measurement of alkaline phosphatase of intestinal origin in plasma by p-bromotetramisole inhibition. Journal of Clinical Pathology, 44(3), 236-237.

Laczko-Dobos, H., Ughy, B., Toth, S. Z., Komenda, J., Zsiros, O., Domonkos, I., . . . Gombos, Z. (2008). Role of phosphatidylglycerol in the function and assembly of Photosystem II reaction center, studied in a cdsA-inactivated PAL mutant strain of Synechocystis sp. PCC6803 that lacks phycobilisomes. Biochimica Et Biophysica Acta-Bioenergetics, 1777(9), 1184-1194. doi: DOI 10.1016/j.bbabio.2008.06.003

Liu, Y. (2008). Magnetic Field Effects on Photosynthetic Reactions.

Liu, Y. Z., Wang, W., Ru, S. G., \& Zhao, Y. Y. (2008). Evidence for the production of a proteinaceous hemolytic exotoxin by wild-type strain of Synechocystis sp PCC 6803 (Cyanobacteria). Journal of Applied Phycology, 20(1), 8995. doi: DOI 10.1007/s10811-007-9185-4

Mattoo, A. K., Giardi, M. T., Raskind, A., \& Edelman, M. (1999). Dynamic metabolism of photosystem II reaction center proteins and pigments. Physiologia Plantarum, 107(4), 454-461. doi: DOI 10.1034/j.1399-3054.1999.100412.x

Mihoub, M., El May, A., Aloui, A., Chatti, A., \& Landoulsi, A. (2012). Effects of static magnetic fields on growth and membrane lipid composition of $<$ i $>$ Salmonella typhimurium $</$ i $>$ wild-type and $<$ i $>$ dam $</$ i $>$ mutant strains. International Journal Of Food Microbiology, 157(2), 259-266.

Nascimento, S. M., \& Azevedo, S. F. O. (1999). Changes in cellular components in a (Cyano- 
bacterium Synechocystis aquatilis) f. salina subjected to different N//P ratios: an ecophysiological study. Environmental Toxicology, 14, 37-44.

Olive, J., Ajlani, G., Astier, C., Recouvreur, M., \& Vernotte, C. (1997). Ultrastructure and light adaptation of phycobilisome mutants of $S y$ nechocystis PCC 6803. Biochimica Et Biophysica Acta-Bioenergetics, 1319(2-3), 275-282. doi: Doi 10.1016/S0005-2728(96)00168-5

Pawlik-Skowrofiska, B. K., R. Skowrofiski, T. . (1997). The impact of inorganic tin on the planktonic cyanobacterium Synechocystis aquatilis: the effect of $\mathrm{pH}$ and humic acid. Environmental Pollution, 97(1-2), 65-69.

Pazur, A., \& Scheer, H. (1992). The growth of freshwater green algae in weak alternating magnetic fields of $7.8 \mathrm{~Hz}$ frequency. Zeitschrift für Naturforschung C, 47c(9-10), 690-694.

Pérez, D. S., Soraci, A. L., \& Tapia, M. O. (2008). Cianobacterias y cianotoxinas: rol de las micriocistinas en la salud humana y animal y su detección en muestras de agua. Analecta Veterinaria, 28(1), 48-56.

Ramos, A. A., F.G. Fernández-Sevilla, J. M. González, C. V. Bermejo, R. (2011). Development of a process for large-scale purification of c-phycocyanin from Synechocystis aquatilis using expanded bed adsorption chromatography. Journal of Chromatography B, 879(7-8), 511-519. doi: DOI 10.1016/j.jchromb.2011.01.013

Raven, J. A. (1988). Limits to growth. In M. A. Borowitzka \& L. J. Borowitzka (Eds.), Microalgal Biotechnology (pp. 257-287). Cambridge: Cambridge University Press.

Rivas, J., Fontes, A. G., Moreno, J., Rodríguez, H., \& Vargas, M. A. (1992). Determinación de componentes celulares de microalgas. Sociedad Española de Fisiología Vegetal, Boletín 17, 3137.

Sigelman, H. W., \& Kycia, J. H. (1978). Algal biliproteins. In J. A. Hellesbust \& J. S. Craige (Eds.), Handbook of Phycological methods: phycological and biochemical methods (pp. 71-79). Cambridge: Cambridge University Press.

Singh, S. S., Tiwari, S. P., Abraham, J., Rai, S., \& Rai, A. K. (1994). Magnetobiological effects on a cyanobacterium, Anabaena doliolum. Electro- magnetic Biolological Medicine, 13, 227-235.

Spurr, A. R. (1969). A low-viscosity epoxy resin embedding medium for electron microscopy. J. Ultrastruct. Res., 26, 31-43.

Ugwu, C. U. O., J.C. Tanaka, H. (2005). Light/dark cyclic movement of algal culture (Synechocystis aquatilis) in outdoor inclined tubular photobioreactor equipped with static mixers for efficient production of biomass. Biotechnology Letters, 27, 75-78.

van de Meene, A. M. L., Hohmann-Marriott, M. F., Vermaas, W. F. J., \& Roberson, R. W. (2006). The three-dimensional structure of the cyanobacterium Synechocystis sp PCC 6803. Archives of Microbiology, 184(5), 259-270. doi: DOI 10.1007/s00203-005-0027-y

van de Meene, A. M. L., Sharp, W. P., McDaniel, J. H., Friedrich, H., Vermaas, W. F. J., \& Roberson, R. W. (2012). Gross morphological changes in thylakoid membrane structure are associated with photosystem I deletion in Synechocystis sp. PCC 6803. Biochimica et Biophysica Acta, 1818, 1427-1434.

Velizarov, S. (1999). Electric and magnetic fields in microbial biotechnology: possibilities, limitations, and perspectives. Electro and Magnetobiology, 18(2), 185-212.

Wang, H. Y., Zeng, X. B., \& Gui, S. Y. (2006). Growth of Chlorella vulgaris under different magnetic treatments. Progress in Modern Biomedicine, 12. doi: CNKI:ISSN:1673-6273.0.2006-12-045

Zhi-Yong, L., Si-Yuan, G., Lin, L., \& Miao-Yan, C. (2007). Effects of electromagnetic field on the batch cultivation and nutritional composition of Spirulina platensis in an air-lift photobioreactor. Bioresource Technology, 98, 700-705.

\section{$48 \quad$ Cumbres}

